\title{
Sodium bicarbonate and HEPES as buffer components for cooling the semen of pony stallions
}

\section{Bicarbonato de sódio e HEPES como tampões para o resfrigeração de sêmen de pôneis}

\author{
Janislene Mach Trentin ${ }^{1 *}$; Luiz Augusto Machado Centeno²; \\ Taison de Souza Balestrin ${ }^{3}$; Thainá Minela ${ }^{4}$; Guilherme Machado Zanatta ${ }^{5}$; \\ Gilson Antonio Pessoa ${ }^{6}$; Mara Iolanda Batistella Rubin ${ }^{6}$
}

\begin{abstract}
The composition of semen diluents can modify its viability during cooling. The buffering effects of HEPES and sodium bicarbonate were evaluated considering the $\mathrm{pH}$ and sperm viability. The semen of seven adult Brazilian ponies was evaluated before and after cooling at $5^{\circ} \mathrm{C}$ for $24 \mathrm{~h}$ and $48 \mathrm{~h}$. A non-buffered skim milk powder extender $(\mathrm{C})$ and the same extender buffered with sodium bicarbonate (SB) and HEPES (H) were used. After dilution, semen (three ejaculates/pony) was centrifuged and the seminal plasma discarded. Sperm was then diluted with SB, H or C and its concentration adjusted to 50 x $10^{6} \mathrm{sptz} / \mathrm{mL}$. Progressive motility evaluated after dilution showed similar results with all extenders (71.42\% (SB), $74.28 \%(\mathrm{H})$, and $74.52 \%(\mathrm{C}))$. Sperm motility was evaluated $24 \mathrm{~h}$ and $48 \mathrm{~h}$ after cooling for SB $(44.76 \%$ and $25.23 \%), \mathrm{H}(51.42 \%$ and $38.09 \%)$ and $\mathrm{C}(54.05 \%$ and $41.66 \%$, respectively). Plasma membrane integrity was similar after exposure to the three extenders $(62.71 \%(\mathrm{SB}), 68.76 \%$ $(\mathrm{H})$, and $69.23 \%(\mathrm{C})$ ). Mitochondrial activity was higher in SB immediately after dilution $(\mathrm{SB}=1.05 \mathrm{~nm}$, $\mathrm{H}=0.81 \mathrm{~nm}, \mathrm{C}=0.79 \mathrm{~nm})$, and after $24 \mathrm{~h}(0.83 \mathrm{~nm}(\mathrm{SB}), 0.73 \mathrm{~nm}(\mathrm{H})$ and $0.64 \mathrm{~nm}(\mathrm{C}))$. After $48 \mathrm{~h}$, the mitochondrial activity decreased to $0.72 \mathrm{~nm}(\mathrm{SB}), 0.69 \mathrm{~nm}(\mathrm{H})$, and $0.63 \mathrm{~nm}(\mathrm{C})(\mathrm{P}>0.05)$. The $\mathrm{pH}$, osmolarity and $\mathrm{pH}$ after $48 \mathrm{~h}$ of cooling of the diluted semen were higher in $\mathrm{SB}(8 ; 382 ; 7.9)$, intermediate in $\mathrm{H}(7.5 ; 362 ; 7.32)$ and lower in $\mathrm{C}(7.16 ; 350 ; 7.07)$. Lipid peroxidation and its induction were similar in all groups. Data were analyzed by analysis of variance (ANOVA), and Duncan's test was used to evaluate the significant differences $(\mathrm{P}<0.05)$. Sodium bicarbonate reduced the progressive motility and increased the semen $\mathrm{pH}$. The extender $\mathrm{C}$ was considered more appropriate for immediate use in artificial insemination. The non-buffered and HEPES-buffered extenders were considered appropriate for the cooling of equine semen for $48 \mathrm{~h}$ at $5^{\circ} \mathrm{C}$.
\end{abstract}

Key words: Dilution. Equine. Extender. Motility. pH. Spermatozoa.

\footnotetext{
${ }^{1}$ Médica Veterinária, Discente de Doutorado, Programa de Pós-Graduação em Medicina Animal: Equinos, Universidade Federal do Rio Grande do Sul, UFRGS, Porto Alegre, RS, Brasil. E-mail: janislenetrentin@yahoo.com.br

${ }^{2}$ Médico Veterinário, Discente de Mestrado, Programa de Pós-Graduação em Medicina Animal: Equinos, UFRGS, Porto Alegre, RS, Brasil. E-mail: luizmachadocenteno@gmail.com

${ }^{3}$ Discente de Medicina Veterinária, Universidade Federal de Santa Maria, UFSM, Santa Maria, RS, Brasil. E-mail: taisonbalestrin@ yahoo.com.br

${ }^{4}$ Médica Veterinária, UFSM, Santa Maria, RS, Brasil. E-mail: thainaminela@gmail.com

${ }^{5}$ Médico Veterinário, Discente de Mestrado, Programa de Pós-Graduação em Reprodução Animal, Faculdade de Medicina Veterinária e Zootecnia, Universidade de São Paulo, USP, São Paulo, SP, Brasil. E-mail: guilhermemzanatta@gmail.com

${ }^{6}$ Médicos Veterinários, Profs. Drs., Departamento Clinica de Grandes Animais, UFSM, Santa Maria, RS, Brasil. E-mail: gilsonpessoavet@yahoo.com.br; mararubin90@yahoo.com.br

* Author for correspondence
} 


\section{Resumo}

A composição dos diluentes de sêmen pode modificar sua viabilidade durante o processo de resfriamento. $\mathrm{O}$ efeito de tamponamento do HEPES e Bicarbonato de Sódio foi avaliado considerando o pH e a viabilidade espermática. Sete pôneis brasileiros adultos tiveram seu sêmen avaliado antes e após a refrigeração a $5^{\circ} \mathrm{C}$ durante $24 \mathrm{~h}$ e $48 \mathrm{~h}$. Um diluente de leite em pó desnatado não tamponado (C) e um diluente tamponado com bicarbonato de sódio (SB) ou HEPES $(\mathrm{H})$ foram utilizados. Após a diluição, o sêmen (três ejaculados/ pônei) foi centrifugado e o sobrenadante foi descartado. O sêmen foi então diluído com SB, H ou C e a concentração ajustada para $50 \times 10^{6}$ espermatozoides $/ \mathrm{mL}$. A motilidade progressiva avaliada após a diluição apresentou resultados similares para todos os diluentes $(71,42 \%$ (SB), 74,28\% (H), 74,52\% (C)). A motilidade espermática foi avaliada 24 h e $48 \mathrm{~h}$ após o resfriamento, respectivamente, para SB $(44,76 \%, 25,23 \%), \mathrm{H}(51,42 \%, 38,09 \%)$ e C (54,05\%, 41,66\%). A integridade da membrana plasmática foi semelhante após a exposição aos três diluentes $(62,71 \%(\mathrm{SB}), 68,76 \%(\mathrm{H})$, $69,23 \%(C))$. A atividade mitocondrial após a diluição foi maior em $\mathrm{SB}(\mathrm{SB}=1.05 \mathrm{~nm}, \mathrm{H}=0.81 \mathrm{~nm}, \mathrm{C}$ $=0.79 \mathrm{~nm})$ e após $24 \mathrm{~h}$ foi $0.83 \mathrm{~nm}(\mathrm{SB}), 0.73 \mathrm{~nm}(\mathrm{H})$ e $0.64 \mathrm{~nm}(\mathrm{C})$. A atividade mitocondrial após 48 h diminuiu para $0.72 \mathrm{~nm}(\mathrm{SB}), 0.69 \mathrm{~nm}(\mathrm{H})$ e $0.63 \mathrm{~nm}(\mathrm{C})(\mathrm{P}>0.05)$. O pH, a osmolaridade e o pH do sêmen diluído após as $48 \mathrm{~h}$ de refrigeração foram maiores em $\mathrm{SB}(8 ; 382 ; 7,9)$, intermediário em $\mathrm{H}(7,5$; $362 ; 7,32)$ e menor em C $(7,16 ; 350 ; 7,07)$. A peroxidação lipídica e sua indução foram semelhantes em todos os grupos. As médias foram avaliadas através de análise de variância (ANOVA) e o Teste Duncan foi utilizado para analisar as diferenças significativas $(\mathrm{P}<0.05)$. O bicarbonato de sódio reduziu a motilidade progressiva e aumentou o $\mathrm{pH}$ do sêmen. $\mathrm{O}$ diluente $\mathrm{C}$ foi considerado mais adequado para uso imediato na inseminação artificial. O diluente não tamponado e tampado com HEPES foram considerados apropriados para o resfriamento de sêmen de equino durante $48 \mathrm{~h} \mathrm{a} 5^{\circ} \mathrm{C}$.

Palavras-chave: Diluente. Diluição. Espermatozoides. Equino. Motilidade. pH.

\section{Introduction}

One of the extenders used for cooling equine semen is skimmilk, glucose and antibiotic (KENNEY et al., 1975; BERGERON; MANJUNATH, 2006; FLOREZ-RODRIGUEZ et al., 2014). Extenders are known for their practicality and for the protection afforded to the sperm during cooling (AURICH, 2008), but the longevity of spermatozoa seems to vary according to the extender composition (PAPA et al., 2014; MARTINS et al., 2016). Most diluents are based on skim milk or egg yolk. The protection mechanisms involved are not well elucidated. In milk, the protective effect seems to be related to casein micelles (BATELLIER et al., 2001; LUSIGNAN et al., 2011), while in egg yolk, low density lipoproteins are important (BERGERON; MANJUNATH, 2006; PUGLIESI et al., 2012).

The storage temperature, the rate of cooling, exposure to oxygen, the presence of bacteria, the type of extender, the presence and type of antibiotic added to the extender, and the concentration of seminal plasma (LOVE et al., 2005; KARESKOSKI, KATILA, 2008) during cooling can all influence sperm viability (ORTEGA-FERRUSOLA et al., 2011; LOVE et al., 2012; VIDAMENT et al., 2012; RODRIGUEZ et al., 2014). Besides the preservation of motility, the extender should also guarantee and preserve the integrity of spermatozoa membranes (CRESPILHO et al., 2012), their mitochondria (POMMER et al., 2002), and sperm chromatin.

Substances used in semen extenders must, at the very least, meet the following requirements: a similar or slightly higher osmolarity than the semen (300-350 mOsm/L), and slightly acidic (6.8) to neutral (7.0) $\mathrm{pH}$. Essential components include substances that stabilize the $\mathrm{pH}$ and control microorganism growth, a readily available source of energy, and ingredients that stabilize membranes and maintain the metabolic function of sperm, as well as neutralizing metabolic substances (MARTINS et al., 2016). Ideally, extender components should not interfere with the results of semen evaluation (AURICH, 2011); however, some components in extenders can interfere in computer-assisted semen analysis (FLOREZ-RODRIGUEZ et al., 2014), even reducing the efficiency of sperm sexing by 
flow cytometry (MORRIS, 2005).

During storage, sperm and contaminating bacteria generally produce metabolites that may reduce the $\mathrm{pH}$ of the extender, reducing both sperm metabolism and motility (YÁNIZ et al., 2011). These alterations can cause sperm death due to drastic changes in $\mathrm{pH}$, justifying the addition of buffers to the extender (GRAHAM et al., 1972; HOLT, 2000).

Kenney et al. (1975) previously described sodium bicarbonate as a buffer. Later, HEPES (N-2hydroxyethyl piperazine-N'-2-ethanesulfonic acid), an organic buffer, was the subject of studies on maturation media for embryo production (GOOD et al., 1996; DOWNS; MASTROPOLO, 1997), and its use is currently still indicated (SWAIN, 2010; PARRISH, 2014).

Ponies and miniature horses are used both as working animals and as riding animals for children. In addition, data generated by research work using ponies can also be considered relevant to horses. Preliminary studies in our laboratory have demonstrated that sodium bicarbonate can have a detrimental effect on cooled semen. The aim of this study was to evaluate an alternative to sodium bicarbonate as an extender for cooled semen.

Multiple extenders have been developed in the last few years to preserve equine semen in storage (GIBB, AITKEN, 2016). While buffers have been compared, there is need for further investigation in this area. The objective of this study was to evaluate the effect of an equine semen extender containing skim milk (powder), without buffer and buffered with sodium bicarbonate or HEPES, on sperm viability and $\mathrm{pH}$ in fresh semen, and in semen cooled for $24 \mathrm{~h}$ or $48 \mathrm{~h}$ at $5^{\circ} \mathrm{C}$.

\section{Materials and Methods}

\section{Locale of the experiment and animal management}

The study was performed from October through December (springtime in the southern hemisphere) during the 2014 breeding season at the Laboratory of Animal Embryology of the Federal University of Santa Maria (UFSM), Santa Maria/RS, Brazil (29 $41^{\prime}-03^{\circ}$ South, $53^{\circ} 48^{\prime}-25^{\circ}$ West). Seven pony stallions of the Brazilian breed, aged 9 to 13 years, were fed once daily with oat grains and alfalfa, with water freely available. They were located in a paddock and kept under the same management conditions. The Committee of Ethics in Animal Experimentation from the Federal University of Santa Maria approved all of the procedures performed in these experiments, according to protocol number 065/2013.

\section{Semen collection and analyses}

Semen of all ponies was routinely collected with an artificial vagina (Hannover Model; Minitube, Tiefenbach, Germany) twice a week, before and during the experiment. Three ejaculates per pony were used in the study. Ejaculates were filtered with sterile gauze and analyzed macroscopically to assess their volume, color and appearance. Evaluation of sperm concentration was performed in a Neubauer hemocytometer counting chamber. The total volume of the ejaculate was split into three fractions and diluted 1:1 (semen:extender) in three different extenders (Table 1), followed by centrifugation at $450 \mathrm{x}$ g for $10 \mathrm{~min}$ to remove seminal plasma. The $\mathrm{pH}$ and osmolarity of the extenders was not fixed, in order to evaluate the effects of the buffers in the diluent, which already contains other chemical components. The concentrations of the buffers were defined after preliminary testing in order to generate a $\mathrm{pH}$ between 7 and 8 . The supernatant was removed, the pellet was resuspended in the extender, and the concentration was adjusted to 50 x $10^{6} \mathrm{sptz} / \mathrm{mL}$. Unless otherwise mentioned, the chemical components were purchased from Sigma Aldrich (St. Louis, MO, USA). 
Table 1. Chemical composition of extender solutions containing different buffers tested in the semen of Brazilian ponies.

\begin{tabular}{lccc}
\hline Extender/Component & Sodium bicarbonate & HEPES & Control \\
\hline Skim milk powder & $2.4 \mathrm{~g}$ & $2.4 \mathrm{~g}$ & $2.4 \mathrm{~g}$ \\
Glucose & $4.9 \mathrm{~g}$ & $4.9 \mathrm{~g}$ & $4.9 \mathrm{~g}$ \\
Sodium bicarbonate & $0.150 \mathrm{~g}$ & - & - \\
HEPES & - & $0.100 \mathrm{~g}$ & - \\
Ultra-pure water & $95 \mathrm{~mL}$ & $95 \mathrm{~mL}$ & $95 \mathrm{~mL}$ \\
\hline
\end{tabular}

One sample from each group of ponies was used for analysis of motility, $\mathrm{pH}$, membrane function (hypoosmotic - HOST), mitochondrial activity (MTT), lipid peroxidation through thiobarbituric acid-reactive substances (TBARS), and peroxidation induced by iron sulfate. The remaining semen samples were refrigerated at $5^{\circ} \mathrm{C}$. New evaluations were performed after refrigeration for $24 \mathrm{~h}$ and 48 h. Before assessment, the samples were warmed for 5 minutes in a dry bath adjusted to $37^{\circ} \mathrm{C}$.

\section{Semen evaluation}

Evaluation of sperm motility was performed subjectively using an optical phase contrast microscope (CBRA, 2013). The $\mathrm{pH}$ of the fresh diluted semen, and of semen that had been stored refrigerated for $24 \mathrm{~h}$ and $48 \mathrm{~h}$, was determined $(\mathrm{pH}$ Meter Tec-2, Tecnal).

\section{Membrane functionality test (HOST)}

The functional membrane integrity was evaluated using the hypoosmotic test, in a 2:1 dilution (distilled water:semen), adjusting the osmolarity to around $100 \mathrm{mOsm} / \mathrm{kg} \mathrm{H} \mathrm{H}_{2} \mathrm{O}-1$. The samples were incubated at $37^{\circ} \mathrm{C}$ for eight minutes according a protocol adjusted for horses (LAGARES et al., 2000). Subsequently, analysis was conducted using a phase contrast microscope (400x), on a slide and under a cover glass, counting 100 sperm per sample.
Mitochondrial activity assessed by reduction of tetrazolium (MTT assay)

The MTT reduction assay depends on the ability of metabolically active cells to reduce the tetrazolium salt (3 [4,5-dimethylthiazol-2-y1] -2,5-diphenyl tetrazolium bromide) to formazan (AZIZ et al., 2005). MTT is a yellow salt that is reduced to formazan by the action of dehydrogenases of metabolically active cells, forming insoluble purple crystals in water. These crystals can be solubilized with organic solvents. The intensity of the purple color can be measured spectrophotometrically and has a direct relationship with the metabolic activity of the cells in the samples.

To assess the mitochondrial activity, a semen sample in each extender (sodium bicarbonate, HEPES, or unbuffered extender) was centrifuged at $600 \mathrm{x}$ g for $10 \mathrm{~min}$, the supernatant discarded, and the pellet resuspended in the appropriate extender, adjusting the concentration to $100 \times 10^{6} \mathrm{sptz} / \mathrm{mL}$. Two aliquots of $200 \mu \mathrm{L}$ at $100 \times 10^{6} \mathrm{sptz} / \mathrm{mL}$ were placed in $2 \mathrm{~mL}$ microcentrifuge tubes. Tetrazolium solution, $20 \mu \mathrm{L}$ ( $5 \mathrm{mg} / \mathrm{mL}$ thiazolyl blue tetrazolium bromide; M2128, Sigma-Aldrich) in saline PBS, was added to the tubes, which were then incubated for $30 \mathrm{~min}$ in a water bath at $37^{\circ} \mathrm{C}$.

The microcentrifuge tubes were centrifuged at $12000 \mathrm{x} \mathrm{g}$ for $5 \mathrm{~min}$ after the addition of 200 $\mu \mathrm{L}$ of a $0.04 \mathrm{~N} \mathrm{HCl-isopropanol} \mathrm{solution.} \mathrm{The}$ mitochondrial metabolic activity was estimated by UV visible spectrophotometry of the supernatant at a wavelength of $540 \mathrm{~nm}$. The reference sample used was the skim milk extender solution containing 
glucose, with the addition of tetrazolium and $0.04 \mathrm{~N}$ $\mathrm{HCl}$-isopropanol. The aliquots from each stallion were analyzed in triplicate.

Assay of lipid peroxidation by thiobarbituric acid (TBARS)

A sample of each tested extender (containing sodium bicarbonate, HEPES, or unbuffered) containing $10 \times 10^{6}$ sperm adjusted to $80 \mu \mathrm{L}$ was used for the lipid peroxidation test by thiobarbituric acid (TBARS).

The TBARS concentration in the semen samples was determined in microcentrifuge tubes containing $0.2 \mathrm{~mL}$ of thiobarbituric acid (TBA), $0.2 \mathrm{~mL}$ of acetic acid solution, $0.04 \mathrm{~mL}$ of ultra-pure water, 0.08 $\mathrm{mL}$ of the sample, and $0.08 \mathrm{~mL}$ of sodium dodecyl sulfate (SDS). The tubes containing this mixture were incubated at $100{ }^{\circ} \mathrm{C}$ for $2 \mathrm{~h}$, and then cooled in a container with ice. The samples were centrifuged at $800 \mathrm{x} \mathrm{g}$ for $5 \mathrm{~min}$, and the absorbances of the supernatants were measured in a spectrophotometer. The assay was performed in triplicate and the absorbance of the samples was measured with a 532 $\mathrm{nm}$ filter. As reference samples, extenders without semen samples were also evaluated. All analyses were performed in a UV-VIS spectrophotometer (Perkin Elmer - Lambda 25) at $25^{\circ} \mathrm{C}$.

\section{Induction of lipid peroxidation by iron sulfate}

To induce lipid peroxidation, samples of each tested extender containing $10 \times 10^{6}$ sperm adjusted to $80 \mu \mathrm{L}$ were added to $0.02 \mathrm{~mL}$ of ferrous sulfate and $0.02 \mathrm{~mL}$ of ascorbic acid. These samples were incubated in a water bath at $37{ }^{\circ} \mathrm{C}$ for one hour. Then, $0.2 \mathrm{~mL}$ of trichloroacetic acid was added to each sample. All samples were centrifuged at 3000 $\mathrm{x} g$ for $10 \mathrm{~min}$. The supernatant was transferred to a microcentrifuge tube and $0.2 \mathrm{ml}$ of thiobarbituric acid (TBA) was added. The specimens were incubated at $100^{\circ} \mathrm{C}$ for one hour and cooled. The samples were then centrifuged following the protocol used for TBARS. This procedure is known as induced or catalyzed lipid peroxidation by iron. It is designed to measure the full potential of the sample to generate the radical in question, and is related to lipid peroxidation.

\section{Statistical analysis}

All statistical analyses were performed using SAS 9.2 software (SAS Institute Inc., Cary, NC, USA). Data were investigated using analysis of variance (ANOVA) and comparisons among the extenders containing sodium bicarbonate, HEPES, or without buffer at $0 \mathrm{~h}, 24 \mathrm{~h}$, and $48 \mathrm{~h}$ were performed using Duncan test. Graphs were prepared using Graph Prism software. Differences among groups were considered statistically significant when the probability (P-value) was less than or equal to 0.05 .

\section{Results}

The progressive motility of the semen immediately after dilution was similar $(\mathrm{P}=0.1367)$ in the extenders containing sodium bicarbonate (SB) and HEPES (H) and in the non-buffered skim milk powder extender $(\mathrm{C}=$ control). Semen in the extender containing SB showed a lower percentage of spermatozoa exhibiting progressive motility compared with the HEPES $(\mathrm{H})$, and $\mathrm{C}$ extenders after $24 \mathrm{~h}(\mathrm{P}=0.0083)$ and $48 \mathrm{~h}(\mathrm{P}<0.0001)$ of refrigeration. The integrity of the sperm membrane (HOST) was similar among the $\mathrm{SB}, \mathrm{H}$, and $\mathrm{C}$ extenders immediately after dilution, and after $24 \mathrm{~h}$ and $48 \mathrm{~h}$ of cooling (Table 2; Figure1). 
Table 2. Means and standard deviations of progressive motility, HOST test, mitochondrial activity, and $\mathrm{pH}$ values in three dilutions, analyzed fresh, and after $24 \mathrm{~h}$ and $48 \mathrm{~h}$ of cooling at $5^{\circ} \mathrm{C}$.

\begin{tabular}{|c|c|c|c|c|}
\hline $\begin{array}{c}\text { Dilution } \\
\text { Preservation }\end{array}$ & $\begin{array}{c}\text { Sodium } \\
\text { bicarbonate }\end{array}$ & HEPES & Control & P Value \\
\hline \multicolumn{5}{|c|}{ Progressive motility } \\
\hline Fresh & $71.42 \pm 5.94 \mathrm{Aa}$ & $74.28 \pm 5.31^{\mathrm{Aa}}$ & $74.52 \pm 5.22 \mathrm{Aa}$ & $>0.05$ \\
\hline $24 \mathrm{~h}$ & $44.76 \pm 12.59^{\mathrm{Bb}}$ & $51.42 \pm 6.91^{\mathrm{Ba}}$ & $54.04 \pm 8.47 \mathrm{Ba}$ & $<0.0083$ \\
\hline $48 \mathrm{~h}$ & $25.23 \pm 12.59^{\mathrm{Cb}}$ & $38.09 \pm 9.67 \mathrm{Ca}$ & $41.66 \pm 6.58^{\mathrm{Ca}}$ & $<0.0001$ \\
\hline \multicolumn{5}{|c|}{ Hypoosmotic } \\
\hline Fresh & $62.71 \pm 11^{\mathrm{Aa}}$ & $68.76 \pm 9.75^{\mathrm{Aa}}$ & $69.23 \pm 9.5^{\mathrm{Aa}}$ & $>0.05$ \\
\hline $24 \mathrm{~h}$ & $35.95 \pm 13.08^{\mathrm{Ba}}$ & $42.47 \pm 13.67 \mathrm{Ba}$ & $39.47 \pm 12.1^{\mathrm{Ba}}$ & $>0.05$ \\
\hline $48 \mathrm{~h}$ & $27.76 \pm 11.96^{\mathrm{Ca}}$ & $33.09 \pm 11.97 \mathrm{Ca}$ & $33.09 \pm 13.6^{\mathrm{Ba}}$ & $>0.05$ \\
\hline \multicolumn{5}{|c|}{$\operatorname{MTT}(n m)$} \\
\hline Fresh & $1.05 \pm 0.35^{\mathrm{Aa}}$ & $0.818 \pm 0.23^{\mathrm{Ab}}$ & $0.79 \pm 0.28^{\mathrm{Ab}}$ & 0.011 \\
\hline $24 \mathrm{~h}$ & $0.83 \pm 0.32^{\mathrm{Ba}}$ & $0.73 \pm 0.26^{\mathrm{Aab}}$ & $0.64 \pm 0.18^{\mathrm{Ab}}$ & 0.0685 \\
\hline $48 h$ & $0.72 \pm 0.3^{\mathrm{Ba}}$ & $0.69 \pm 0.31^{\mathrm{Aa}}$ & $0.63 \pm 0.27^{\mathrm{Aa}}$ & $>0.05$ \\
\hline \multicolumn{5}{|c|}{ pH } \\
\hline Fresh & $7.82 \pm 0.1^{\mathrm{Aa}}$ & $7.46 \pm 0.14^{\mathrm{Ab}}$ & $7.08 \pm 0.23^{\mathrm{Ac}}$ & $<0.0001$ \\
\hline $24 \mathrm{~h}$ & $7.85 \pm 0.18^{\mathrm{Aa}}$ & $7.43 \pm 0.14^{\mathrm{Ab}}$ & $7.07 \pm 0.12^{\mathrm{Ac}}$ & $<0.0001$ \\
\hline $48 \mathrm{~h}$ & $7.9 \pm 0.15^{\mathrm{Aa}}$ & $7.32 \pm 0.21^{\mathrm{Bb}}$ & $7.07 \pm 0.15^{\mathrm{Ac}}$ & $<0.0001$ \\
\hline
\end{tabular}

$\overline{a, b, c}$ different letters in lower case mean difference within a row $(\mathrm{P}<0.05)$

$A, B, C$ values with different uppercase superscripts differ within a column $(\mathrm{P}<0.05)$.

Figure 1. Spermatozoa reactive (A), and non-reactive (B), to the hypoosmotic test.

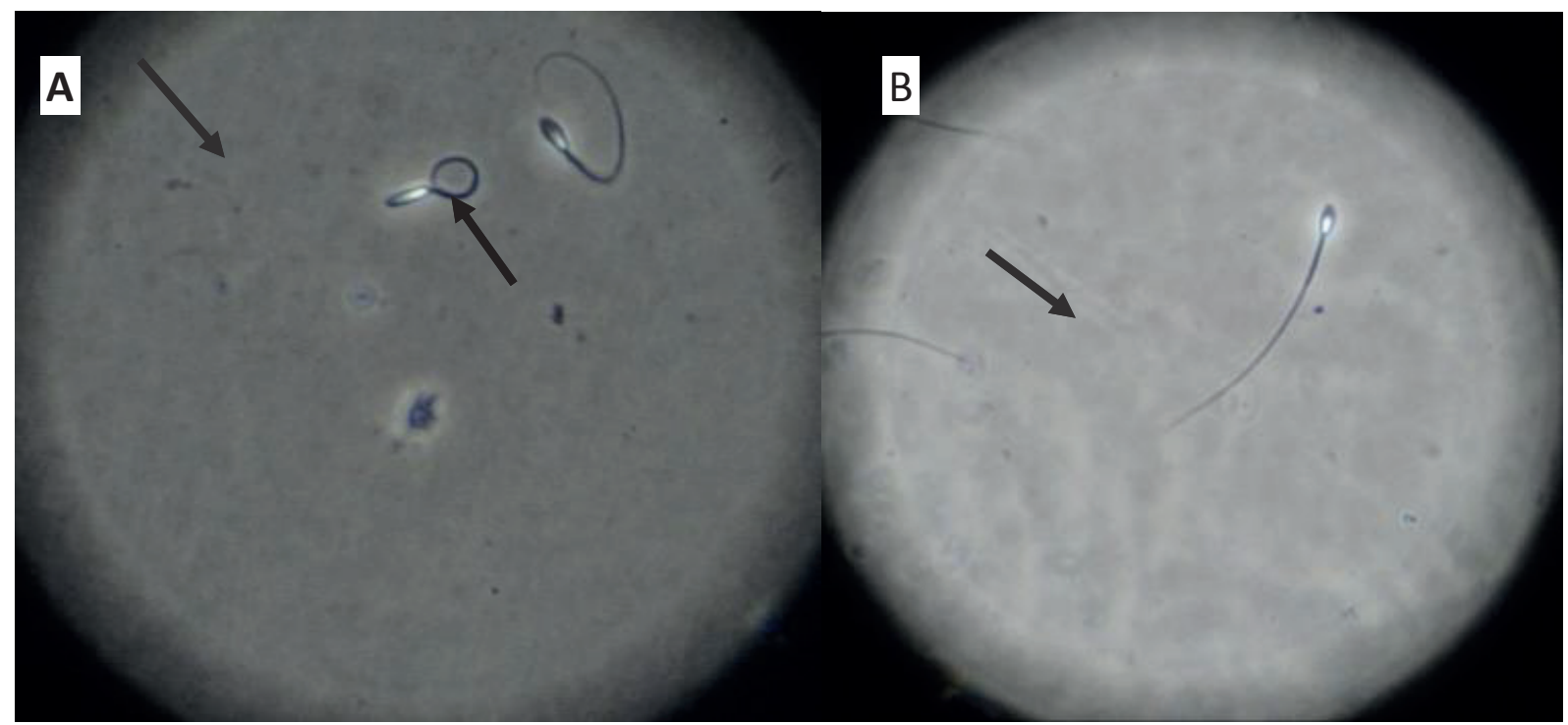


After dilution, the highest mitochondrial activity was observed in semen in extender SB, with lower activity in the extenders with $\mathrm{H}$ and without buffer $(\mathrm{P}=0.01)$. After $24 \mathrm{~h}$ of cooling, the activity in extenders $\mathrm{SB}$ and $\mathrm{H}$ was similar, while semen in extender $\mathrm{C}$ showed lower activity. Mitochondrial activity of semen samples after $48 \mathrm{~h}$ of cooling was similar among the three extenders $(\mathrm{P}=0.585)$. Comparisons with the absorbance of the reference sample solution (skim milk extender solution with glucose) showed that extender SB had a higher absorbance than the other extenders.

The average $\mathrm{pH}$ of the pony semen was $7.52 \pm$ 0.04. Assessing the $\mathrm{pH}$ results, it is interesting to note that the extender containing sodium bicarbonate had the highest $\mathrm{pH}$ value before cooling, after
$24 \mathrm{~h}$ refrigeration, and also after $48 \mathrm{~h}$ of cooling. Intermediate $\mathrm{pH}$ values were observed in diluent $\mathrm{H}$. Lower $\mathrm{pH}$ values were observed in diluent $\mathrm{C}$ (Figure 2), which remained stable after up to $48 \mathrm{~h}$ of cooling ( $\mathrm{P}<0.0001)$. The $\mathrm{pH}$ of the extenders (Figure 3 ) immediately after preparation, and after $24 \mathrm{~h}$ and $48 \mathrm{~h}$ of cooling, behaved similarly to $\mathrm{pH}$ of the semen diluted in the same extenders (extender $\mathrm{SB}=$ highest $\mathrm{pH}$ value; extender $\mathrm{H}=$ intermediate $\mathrm{pH}$, and solvent $\mathrm{C}=$ lower $\mathrm{pH})(\mathrm{P}<0.0001)$.

The results indicate a higher osmolarity for the sodium bicarbonate extender, intermediate osmolarity of the HEPES extender, and a lower osmolarity for the unbuffered extender $(\mathrm{P}<0.0001)$ after $48 \mathrm{~h}$ of cooling (Figure 4).

Figure 2. The mean $\mathrm{pH}$ values of diluted semen of Brazilian ponies in extender with sodium bicarbonate, HEPES or control (without buffer) before cooling or cooled at $5^{\circ} \mathrm{C}$ for 24 or $48 \mathrm{~h}$. Capital letters indicate differences $(\mathrm{P}<0.0288)$ between time points for each extender.

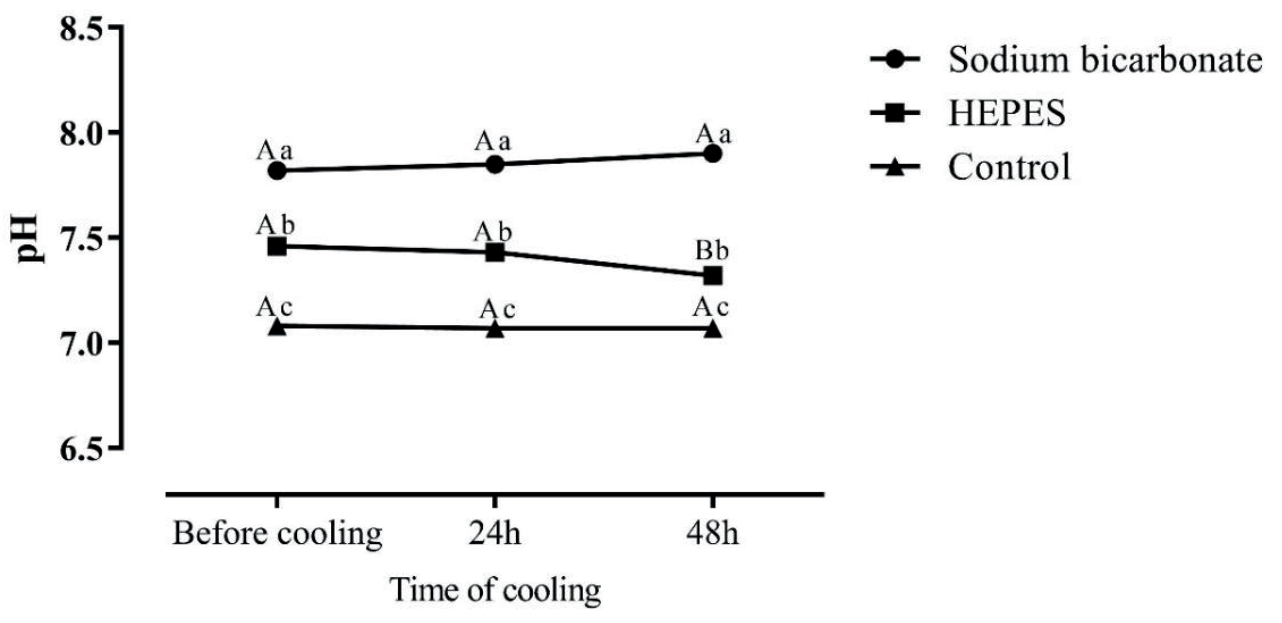


Figure 3. Average $\mathrm{pH}$ values of Brazilian pony semen in extenders containing sodium bicarbonate, HEPES or control (without buffer) after dilution, or after $24 \mathrm{~h}$ or $48 \mathrm{~h}$ of cooling at $5^{\circ} \mathrm{C}(\mathrm{P}=0.0278)$. Capital letters indicate differences $(\mathrm{P}<0.05)$ between time points for each extender.

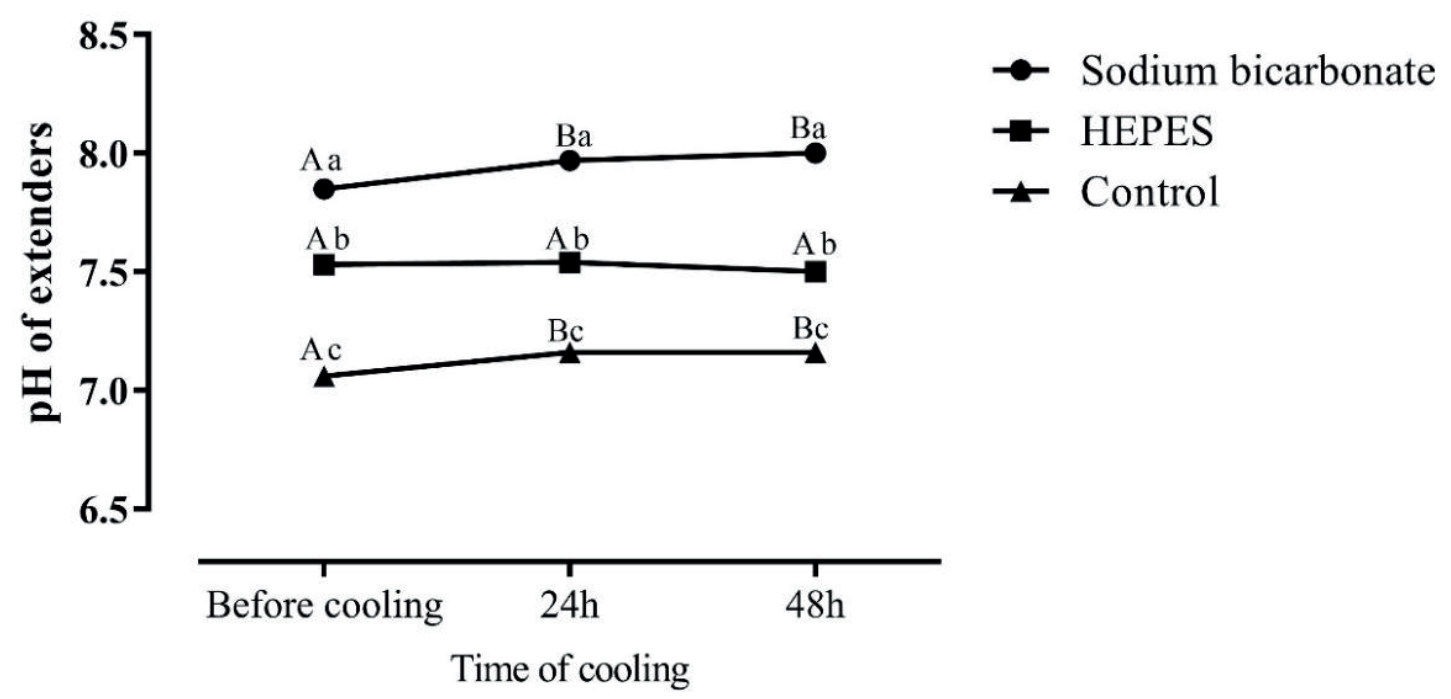

Figure 4. Mean osmolarity values semen in extenders containing sodium bicarbonate, HEPES or control (without buffer) immediately after dilution, or after refrigeration at $5^{\circ} \mathrm{C}$ for 24 or $48 \mathrm{~h}(\mathrm{P}<0.0001)$. Capital letters indicate differences $(\mathrm{P}<0.05)$ between time points for each extender.

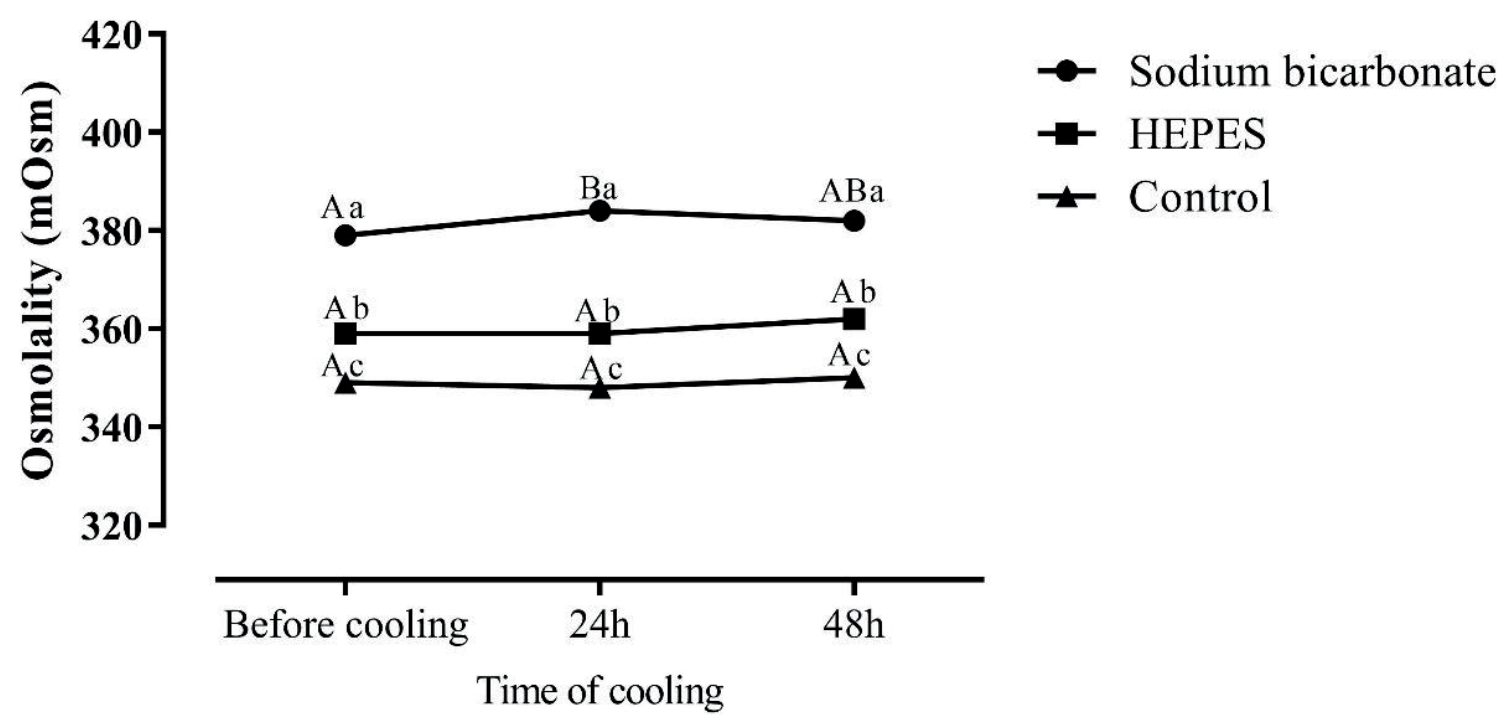


Evaluation of lipid peroxidation and induction of peroxidation immediately after sample preparation showed similar values $(\mathrm{P}>0.05)$ among the extenders SB $(0.16 \pm 0.28$ and $0.09 \pm 0.12), \mathrm{H}(0.19$ \pm 0.22 and $0.06 \pm 0.08)$ and Control $(0.24 \pm 0.18$ and $0.06 \pm 0.11$, respectively) in both tests. Lipid peroxidation and induction of peroxidation after 48 $\mathrm{h}$ of cooling was also similar among the extenders.

\section{Discussion}

The use of HEPES in unbuffered skim milk extender solution containing glucose showed better results than did sodium bicarbonate in all evaluations, except for mitochondrial activity before cooling. This observation can be explained because sperm hyperactivation occurs spontaneously in most spermatozoa incubated in media containing bicarbonate and $\mathrm{Ca}^{2+}$ (HINRICHS; LOUX, 2012; MACÍAS-GARCÍA et al., 2015).

Assessment of sperm motility allowed us to state that there was no difference effect between sperm diluted in HEPES buffered extender $(\mathrm{H})$ and unbuffered extender $(\mathrm{C})$. This suggests that the addition of the buffer did not affect the motility of the spermatozoa at $5^{\circ} \mathrm{C}$; nonetheless, its addition was not necessary.

In the absence of sodium bicarbonate, sperm do not lose their membrane integrity and sperm capacitation is minimal, but when exposed to sodium bicarbonate, sperm becomes vulnerable to membrane rupture and cell death (RATHI et al., 2001). Furthermore, sodium bicarbonate leads to changes in the structure of the plasma membrane lipid in equine sperm (GADELLA; HARRISON, 2000). Induction of the acrosome reaction was observed when sperm were incubated in medium containing sodium bicarbonate; in the absence of bicarbonate, the acrosome reaction was not observed (RATHI et al., 2001). Interestingly, Foster et al. (2011) reported that observed damage to sperm membranes is significant only after $48 \mathrm{~h}$ of cooling.
The $\mathrm{pH}$ of equine semen ranges between 6.8 and 7.0 but is influenced by several factors. Extenders should have a buffering effect on the $\mathrm{pH}$ of semen diluted to balance the production of metabolic substances from sperm or bacteria (AURICH, 2011). Most milk-based extenders have a $\mathrm{pH}$ of about 6.6 (PICKETT; AMANN, 1987). Here, addition of buffers to the extender led to changes in the $\mathrm{pH}$ value. When assessing only the $\mathrm{pH}$ of the extender during $48 \mathrm{~h}$ of cooling, our evaluation highlights that the HEPES extender showed the least variation between 0 and 48 hours; nevertheless, in extender $\mathrm{C}$ values closer to physiological conditions were observed. It must be emphasized here that the necessity of adding a buffer to semen should be carefully examined, since the absence of the buffer in the diluent did not impair sperm membrane integrity or motility. Furthermore, the addition of buffers to the extenders caused an increase in the $\mathrm{pH}$ of the medium using either sodium bicarbonate or HEPES.

Osmotic stress reduces the viability and mitochondrial membrane potential of sperm, and also increases superoxide anion generation and alters protein tyrosine phosphorylation in equine spermatozoa (BALL; VO, 2001; POMMER et al., 2002; BURNAUGH et al., 2010). Equine spermatozoa are more prone to hypotonic- rather than hypertonic-induced damage (POMMER et al., 2002; BURNAUGH et al., 2010). Meanwhile, the incubation of spermatozoa in nonisosmotic media resulted in an increase in oxygen free radical generation (BURNAUGH et al., 2010). Stallion spermatozoa are more sensitive to osmotic shocks than to a given anisosmotic environment, and changes in osmolarity are more deleterious to mitochondria than to the plasma membrane (GARCÍA et al., 2012). The osmolarity of semen extenders ranges between 250 and $400 \mathrm{mOsm} / \mathrm{L}$ (KATILA, 1997). In our study, the osmolarity was higher $(379 \pm 4.18$ before cooling, $384 \pm 4.18$ in $24 \mathrm{~h}$ after cooling, and $382 \pm 2.67 \mathrm{mOsm} / \mathrm{L}$ in $48 \mathrm{~h}$ after cooling) in the extender containing sodium bicarbonate. 
It has been proposed that sodium bicarbonate activates adenylate cyclase, either directly or indirectly, causing $\mathrm{Ca}^{2+}$ increases (CHRISTENSEN et al., 1996) and, thus, raising intracellular concentrations of cAMP. This, in turn, induces sperm hyperactivation (WHITE; AITKEN, 1989) that may be associated with increased degradation of the tetrazolium salt, which would explain why the extender with sodium bicarbonate showed the highest value for mitochondrial activity before cooling. After cooling and following the decline in motility, the mitochondrial activity in extender SB also declined, becoming similar to the other diluents after cooling for $48 \mathrm{~h}$.

In milk-based extenders, native phosphocaseinate and $\beta$-lactoglobulin seem to be responsible for maintaining sperm motility (BATELLIER et al., 1997; MANJUNATH, 2012). The usefulness of the skim milk powder extender may be attributed to the antioxidant capacity of the diluted semen, which would explain the similarity of lipid peroxidation among the extenders, as the three diluents contain the same amount of skim milk. It has been reported (KANKOFER et al., 2005) that dilution of semen only with milk diluent results in a significant increase in the antioxidant capacity of the diluted semen. The addition of skim milk to equine semen extender for cooling at $5^{\circ} \mathrm{C}$ seems to play a crucial role in sperm preservation (KENNEY et al., 1975; FLOREZ-RODRIGUEZ et al., 2014), but to our knowledge there is little research about semen extenders in ponies (NEVES et al., 2006).

\section{Conclusion}

In ponies, skim milk powder extender with or without HEPES buffer provides superior sperm viability compared with the same extender buffered with sodium bicarbonate. Sodium bicarbonate in pony semen extender reduces sperm motility, and causes increased $\mathrm{pH}$. There is no need to buffer the skim milk extender for routine use. HEPES extender and the diluent without buffer are both appropriate for cooling pony sperm for up to $48 \mathrm{~h}$ at $5^{\circ} \mathrm{C}$. The addition of buffers results in increased extender $\mathrm{pH}$, resulting in reduced viability. An extender without buffer can be used for cooling pony semen at $5^{\circ} \mathrm{C}$ for $24 \mathrm{~h}$ or $48 \mathrm{~h}$.

\section{References}

AURICH, C. Recent advances in cooled-semen technology. Animal Reproduction Science, Amsterdam, v. 107, n. 3-4, p. 268-275, 2008.

AURICH, C. Semen extenders for cooled semen (Europe). In: MCKINNON, A. O.; SQUIRES, E. L.; VAALA, W. E.; VARNER, D. D. Equine reproduction. $2^{\text {th }}$ ed. Chichester: Wiley-Blackwell, 2011. v. 1, chap. 131, p. 1336-1340.

AZIZ, D. M.; AHLSWEDE, L.; ENBERGS, H. Application of MTT reduction assay to evaluate equine sperm viability. Theriogenology, New York, v. 64, n. 6, p. 1350-1356, 2005.

BALL, B. A.; VO, A. Osmotic tolerance of equine spermatozoa and the effects of soluble cryoprotectants on equine sperm motility viability and mitochondrial membrane potential. Journal of Andrology, Philadelphia, v. 22, n. 6, p. 1061-1069, 2001.

BATELLIER, F.; MAGISTRINI, M.; FAUQUANTZ, J.; PALMER, E. Effect of milk fractions on survival of equine spermatozoa. Theriogenology, New York, v. 48, n. 3, p. 391-410, 1997.

BATELLIER, F.; VIDAMENT, M.; FAUQUANT, J.; DUCHAMP, G.; ARNAUD, G.; YVON, J. M.; MAGISTRINI, M. Advances in cooled semen technology. Animal Reproduction Science, Amsterdam, v. 68, n. 3-4, p. 181-190, 2001.

BERGERON, A.; MANJUNATH, P. New insights towards understanding the mechanisms of sperm protection by egg yolk and milk. Molecular Reproduction and Development, Rhode Island, v. 73, n. 10, p. 13381344, 2006.

BURNAUGH, L.; BALL, B. A.; SABEUR, K.; THOMAS, A. D.; MEYERS, S. A. Osmotic stress stimulates generation of superoxide anion by spermatozoa in horses. Animal Reproduction Science, Amsterdam, v. 117, n. 3-4, p. 249-260, 2010.

CHRISTENSEN, P.; WHITFIELD, C. H.; PARKINSON, T. J. In vitro induction of acrosome reaction in stallion spermatozoa by heparin and A23187. Theriogenology, New York, v. 45, n. 6, p. 1201-1210, 1996. 
COLÉGIO BRASILEIRO DE REPRODUÇÃO ANIMAL - CBRA. Manual para exame andrológico e avaliação de sêmen animal. 3. ed. Belo Horizonte: CBRA, 2013. 104 p.

CRESPILHO, A. M.; SÁ FILHO, M. F.; DELL'AQUA JUNIOR, J. A.; NICHI, M.; MONTEIRO, G. A.; AVANZI, B. R.; MARTINS, A.; PAPA, F. O. Comparison of in vitro and in vivo fertilizing potential of bovine semen frozen in egg yolk or new lecithin based extenders. Livestock Science, Amsterdam, v. 149, n. 1-2, p. 1-6, 2012.

DOWNS, S. M.; MASTROPOLO, A. M. Culture conditions affect meiotic regulation in cumulus cellenclosed mouse oocyte. Molecular Reproduction and Development, Rhode Island, v. 46, n. 4, p. 551-566, 1997.

FLOREZ-RODRIGUEZ, S. A.; PAES DE ARRUDA, R.; BIANCHI-ALVES, M. R.; AFFONSO, F. J.; CARVALHO, H. F.; LEMES, K. M.; LANÇONI, R.; CESAR DE ANDRADE, A. F.; CARVALHO CELEGHINI, E. C. Morphofunctional characterization of cooled sperm with different extenders to use in equineassisted reproduction. Journal of Equine Veterinary Science, New York, v. 34, n. 7, p. 911-917, 2014.

FOSTER, M. L.; VARNER, D. D.; HINRICHS, K.; TEAGUE, S.; LACAZE, K.; BLANCHARD, T. L. Agreement between measures of total motility and membrane integrity in stallion sperm. Theriogenology, New York, v. 75, n. 8, p. 1499-1505, 2011.

GADELLA, B. M.; HARRISON, R. A. The capacitating agent bicarbonate induces protein kinase A-dependent changes in phospholipid transbilayer behavior in the plasma membrane. Development, Washington, v. 127, n. 11, p. 2407-2420, 2000.

GARCÍA, B. M.; MORAN, A. M.; FERNÁNDEZ, L. G.; FERRUSOLA, C. O.; RODRIGUEZ, A. M.; BOLAÑOS, J. M. G.; SILVA, C. M. da; MARTÍNEZ, H. R.; TAPIA, J. A.; PEÑA F. J. The mitochondria of stallion spermatozoa are more sensitive than the plasmalemma to osmoticinduced stress: role of c-Jun N-terminal Kinase (JNK) pathway. Journal of Andrology, Philadelphia, v. 33, n. 1, p. 105-113, 2012.

GIBB, Z.; AITKEN, R. J. Recent developments in stallion semen preservation. Journal of Equine Veterinary Science, New York, v. 43, p. S29-S36, 2016.

GOOD, N. E.; WINGET, G. D.; WINTER, W.; CONNOLLY, T. N.; IZAWA, S.; SINGH, R. M. M. Hydrogen ion buffers for biological research. Biochemistry, Washington, v. 5, n. 2, p. 467-477, 1996.
GRAHAM, E. F.; CRABO, B.; BROWN, K. I. Effects of some zwitterion buffers on the freezing and storage of spermatozoa: 1. Bull. Journal of Dairy Science, Champaign, v. 55, n. 3, p. 372-378, 1972.

HINRICHS, K.; LOUX, S. C. Hyperactivated sperm motility: Are equine sperm different? Journal of Equine Veterinary Science, New York, v. 32, n. 8, p. 441-444, 2012.

HOLT, W. V. Basic aspects of frozen storage of semen. Animal Reproduction Science, Amsterdam, v. 62, n. 1-3, p. 3-22, 2000.

KANKOFER, M.; KOLM, G.; AURICH, J. E.; AURICH, C. Activity of glutathione peroxidase, superoxide dismutase and catalase and lipid peroxidation intensity in stallion semen during storage at $5^{\circ} \mathrm{C}$. Theriogenology, New York, v. 63, n. 5, p. 1354-1365, 2005.

KARESKOSKI, M.; KATILA, T. Components of stallion seminal plasma and the effects of seminal plasma on sperm longevity. Animal Reproduction Science, Amsterdam, v. 107, n. 3-4, p. 249-256, 2008.

KATILA, T. Procedures for handling fresh stallion semen. Theriogenology, New York, v. 46, n. 7, p. 12171227, 1997.

KENNEY, R. M.; BERGMAN, R. V.; COOPER, W. L.; MORSE, G. W. Minimal contamination techniques for breeding mares: techniques and preliminary findings. In: 21ST ANNUAL CONVENTION OF THE AMERICAN ASSOCIATION OF EQUINE PRACTITIONERS, 21., 1975, San Antonio. Proceedings... Lexington: American of Equine Practitioners, 1975. v. 21, p. 327-336..

LAGARES, M. A.; PETZOLDT, R.; SIEME, H.; KLUG, E. Assessing equine sperm-membrane integrity. Andrologia, Berlin, v. 32, n. 3, p. 163-167, 2000.

LOVE, C. C.; BLANCHARD, T. L.; VARNER, D. D.; BRINSKO, S. P.; VOGE, J.; BLISS, S.; SUDDERTH, K.; TEAGUE, S.; LACAZE, K. Effect of daily semen centrifugation and resuspension on the longevity of equine sperm quality following cooled storage. Theriogenology, New York, v. 77, n. 9, p. 1911-1917, 2012.

LOVE, C. C.; BRINSKO, S. P.; RIGBY, S. L.; THOMPSON, J. A.; BLANCHARD, T. L.; VARNER, D. D. Relationship of seminal plasma level and extender type to sperm motility and DNA integrity. Theriogenology, New York, v. 63, n. 6, p. 1584-1591, 2005.

LUSIGNAN, M.; BERGERON, A.; LAFLEUR, M.; MANJUNATH, P. The major proteins of bovine seminal plasma interact with caseins and whey proteins of milk extender. Biology of Reproduction, Utrecht, v. 85, n. 3, p. 457-464, 2011. 
MACÍAS-GARCÍA, B.; GONZÁLEZ-FERNÁNDEZ, L.; LOUX, S. C.; ROCHA, A. M.; GUIMARÃES, T.; PEÑA, F. J.; VARNER, D. D.; HINRICHS, K. Effect of calcium, bicarbonate, and albumin on capacitationrelated events in equine sperm. Reproduction, Bristol, v. 149, n. 1, p. 87-99, 2015.

MANJUNATH, P. New insights into the understanding of the mechanism of sperm protection by extender components. Animal Reproduction, Belo Horizonte, v. 9, n. 4, p. 809-815, 2012.

MARTINS, H. S.; SOUZA, M. R.; PENNA, C. F. A. M.; SILVA, G. C. da; CÔRTES, S. F.; STAHLBERG, R.; LAGARES, M. A. Milk, caseinate and lactoferrin addition to equine semen cooling extenders. Andrologia, Berlin, v. 48, n. 9, p. 950-956, 2016.

MORRIS, L. H. A. Challenges facing sex preselection of stallion spermatozoa. Animal Reproduction Science, Amsterdam, v. 89, n. 1-4, p. 147-157, 2005.

NEVES, A. P.; BUSTAMANTE FILHO, I. C.; TREIN, C. R.; MALSCHITZKY, E.; JOBIM, M. I. M.; MATTOS, R. C. Reproductive parameters and sperm freezability of stallions of the Brazilian pony breed. In: INTERNATIONAL SYMPOSIUM ON EQUINE REPRODUCTION, 9., 2006, Kerkrade. Proceedings... Amsterdam: Elsevier, 2006. v. 94, p. 67-69.

ORTEGA-FERRUSOLA， C.; JOHANNISSON，A.; VEJA, F. J. P.; TAPIA, J. Á.; RODRIGUEZ-MARTINEZ, H.; DALIN, A. M.; MORRELL, J. M. Effect of different extenders and seminal plasma on the susceptibility of equine spermatozoa to lipid peroxidation after singlelayer centrifugation, through Androcoll-E. Journal of Equine Veterinary Science, New York, v. 31, n. 7, p. 411416, 2011.

PAPA, P. M.; RAMIRES-NETO, C.; MONTEIRO, G. A.; SANCLER-SILVA, Y. F. R.; RESENDE, H. L.; FREITAS-DELL'AQUA, C. P.; DELL'AQUA JUNIOR, J. A.; ALVARENGA, M. A.; PAPA, F. O. Sperm parameters and fertility of stallion semen cooled with different extenders. Journal of Equine Veterinary Science, New York, v. 34, n. 1, p. 79, 2014.

PARRISH, J. J. Bovine in vitro fertilization: in vitro oocyte maturation and sperm capacitation with heparin. Theriogenology, New York, v. 81, n. 1, p. 67-73, 2014.

PICKETT, B. W.; AMANN, R. P. Extension and storage of stallion spermatozoa: a review. Equine Veterinary Science, California, v. 7, n. 5, p. 289-302, 1987.
POMMER, A. C.; RUTLLANT, J.; MEYERS, S. A. The role of osmotic resistance on equine spermatozoal function. Theriogenology, New York, v. 58, n. 7, p. 13731384, 2002.

PUGLIESI, G.; CARVALHO, G. R.; RATES, D. M.; KER, P. G.; PEREIRA, M. O.; RENAN, R. O.; MONTEIRO, J. D. S. Viability and fertility of cooled equine semen diluted with skimmed milk or glycine egg yolk-based extenders. Revista Brasileira de Zootecnia, Viçosa, MG, v. 41, n. 12, p. 2411-2417, 2012.

RATHI, R.; COLENBRANDER, B.; BEVERS, M. M.; GADELLA, B. M. Evaluation of in vitro capacitation of stallion spermatozoa. Biology of Reproduction, Utrecht, v. 65 , n. 2, p. 462-470, 2001.

RODRIGUEZ, S. A. F.; ARRUDA, R. P.; BIANCHIALVES, M. R.; AFFONSO, F. J.; LANÇONI, R.; CARVALHO, H. F.; LEMES, K. M.; ANDRADE, A. F. C.; CELEGHINI, E. C. C. Morphofunctional characterization of cooled sperm using different extenders in equine-assisted reproduction. In: ISER. Journal of Equine Veterinary Science, New York, v. 34, n. 1, p. 94, 2014.

SWAIN, J. E. Optimizing the culture environment in the IVF laboratory: impact of $\mathrm{pH}$ and buffer capacity on gamete and embryo quality. Reproductive BioMedicine Online, Oxford, v. 21, n. 1, p. 6-16, 2010.

VIDAMENT, M.; MAGISTRINIA, M.; LE FOLL, Y.; LAVILLAINA, N.; YVONA, J. -M.; DUCHAMPE, G.; BLESBOIS, E. Temperatures from 4 to $15^{\circ} \mathrm{C}$ are suitable for preserving the fertilizing capacity of stallion semen stored for $22 \mathrm{~h}$ or more in INRA96 extender. Theriogenology, New York, v. 78, n. 2, p. 297-307, 2012.

WHITE, D. R.; AITKEN, R. J. Relationship between calcium, cyclic AMP, ATP, and intracellular $\mathrm{pH}$ and the capacity of hamster spermatozoa to express hyperactivated motility. Molecular Reproduction and Development, Rhode Island, v. 22, n. 2, p. 163-177, 1989.

YÁNIZ, J. L.; MATEOS, J. A.; SANTOLARIA, P. Zwitterionic buffers preserve ram semen quality more efficiently than TRIS during storage at $15^{\circ} \mathrm{C}$. Small Ruminant Research, Amsterdam, v. 95, n. 1, p. 54-60, 2011. 